\title{
Holsteins in Puerto Rico: I. Influence of Herd, Year, Age, and Season on Performance ${ }^{1}$
}

\author{
J. K. Camoens, R. E. McDowell, L. D. Van Vleck, and J. D. \\ Rivera Anaya ${ }^{2}$
}

\begin{abstract}
The effects of herd, year, age, season, and their interactions on milk and fat yield, fat percent, days in milk, days dry, and days open for purebred and high grade Holsteins in a tropical environment were determined by analysis of variance using DHIA records from Puerto Rico. There were 33,950 records for calvings from 1967 to 1973 in 62 herds. Herd effects were significant $(\mathrm{P}<.05)$ for all traits, but seasonal effects were significant only for milk yield, fat yield, and days open. Variation among herds significantly influenced all traits except milk yield. Age of calving affected all traits except lactation length and days open. A number of the interacions were also significant.

The statistical model explained $39,40,24,17,13$ and $12 \%$ of the total variation in milk yield, fat yield, fat percent, lactation length, days dry, and days open, respectively. Total variances were $12,900,000 \mathrm{lb}^{2}$ for milk yield and $15,000 \mathrm{lb}^{2}$ for fat yield, which are comparable to those for temperate areas.

It is concluded that the factors affecung the performance of Holsteins in Puerto Rico do not differ markedly from those in temperate countries. The total variation appears large enough to permit selection for higher milk and fat yields. As in temperate regions, length of lactation, length of dry period, and timo of rebreeding (days open) are largely influenced by decisions made on the part of herd owners.
\end{abstract}

\section{INTRODUCTION}

Whether dairying can be successful in the tropics remains an enigma. Some outstanding successes have been reported, but the objection is often raised that these come from government operated farms where conditions would not represent the general farming situation.

${ }^{2}$ Manuscript submitted to Editorial Board June 3, 1975.

${ }^{2}$ Veterinary Officer, Kuantan, Pahang, West Malaysia; Professor, Department of Animal Science, Cornell University, Ithaca, N.Y. and Consultant, University of Puerto Rico, Mayagüez and Río Piedras, P.R.; Professor, Department of Animal Science, Cornell University, Ithaca, N.Y.; and former Director of Department of Animal Husbandry, Agricultural Experiment Station, University of Puerto Rico, Río Piedras, P.R. The authors are grateful to the staff of the Animal Improvement Programs Laboratory, USDA, Beltsville, Md., and to Puerto Rico DHIA officers, for making the DHIA records available. 
There are numerous reports of Bos taurus breeds of dairy cattle failing to adapt to local conditions when imported into tropical areas. However, many of the experiments conducted with cattle imported to the tropics have done little more than test their ability to survive under low nutritional management (17). The opinion that improved dairy breeds are unsuited to tropical environments has led toward production of new strains of cattle from crosses of Bos taurus and Bos indicus types. The objective has been to produce animals adapted to local environments $(12,15,19)$. This approach can be challenged because there is little evidence that measures of physiological adaptability, e.g., low respiration rate, are significantly correlated with animal performance (17).

In view of insufficient evidence to develop guidelines on breeding and management of dairy cattle in the tropics, it is especially appropriate to utilize records of performance of an improved Bos taurus type in a tropical environment, especially when collected from commercial dairy operations. This study deals with the effects of herd, year, age, and season on milk and fat yield, fat percent, lactation length, dry period, and days open of cows classified as Holsteins in DHIA herds in Puerto Rico.

\section{PROCEDURE}

The data consisted of 33,950 lactation records from 62 herds for cows calving from 1967 to 1973 . Review of the records as received from USDA revealed it would be inappropriate to use all the records since biases in estimates of parameters would occur. To minimize biases the following restrictions were imposed: a) only lactation records coded as terminating normally would be considered; b) of these, 305 days would be the upper limit in length; and c) lactations of $<60$ days in duration would be excluded on the premise that environmental conditions occurring before or problems arising during parturition influenced the animal's health. These restrictions reduced the number of records to approximately 19,000 in 25 herds.

The statistical model used for the analysis of each trait was:

$$
\begin{gathered}
X_{i j k l m}=\mu+H_{i}+Y_{j}+A_{k}+S_{l}+H Y_{i j}+H A_{i k}+H S_{i l}+Y A_{j k}+Y S_{j l}+ \\
A S_{k l}+H Y A_{i j k}+H Y S_{i j l}+H A S_{i k l}+Y A S_{j k l}+H Y A S_{i j k l}+e_{i j k l m}
\end{gathered}
$$

where,

$$
\begin{aligned}
X_{i j k l m}= & \text { The observation of a trait on the } m \text { th cow in the } l \text { th } \\
& \text { season of the } k \text { th age group within the } j \text { th year and the } i \text { th } \\
& \text { herd; } \\
\mu & =\text { the population mean common to all records; } \\
H_{i} & =\text { the deviation from the population mean resulting from } \\
& \text { the fixed effect associated with the } i \text { th herd; }
\end{aligned}
$$


$Y_{j} \quad=$ the fixed effect peculiar to the $j$ th year;

$A_{k} \quad=$ the fixed effect attributable to the $k$ th age group;

$S_{l} \quad=$ the fixed seasonal effect associated with the $l$ th season;

$H Y_{i j} \quad=$ the interaction between the $j$ th year and the ith herd;

$H A_{i k}=$ the interaction between the $k$ th age and the $i$ th herd;

$H S_{i l} \quad=$ the interaction between the $l$ th season and the $i$ th herd;

$Y A_{j k}=$ the interaction between the $k$ th age and the $j$ th year;

$Y S_{j l} \quad=$ the interaction between the $l$ th season and the $j$ th year;

$A S_{k l} \quad=$ the interaction between the $l$ th season and the $k$ th age group;

$H Y A_{i j k}=$ the interaction between the $k$ th age, $j$ th year, and ith herd;

$H Y S_{i j l}=$ the interaction between the $l$ th season, $j$ th year, and $i$ th herd;

$H A S_{i k l}=$ the interaction between the $l$ th season, $k$ th age, and $i$ th herd;

$Y A S_{j k l}=$ the interaction between the $l$ th season, $k$ th age, and the $j$ th year;

$H Y A S_{i j k l}=$ the interaction between the $l$ th season, $k$ th age, $j$ th year, and $i$ th herd;

$e_{i j k l m}=$ the random error associated with each observation with expected mean zero and variance $\sigma^{2}$.

Since the model was multifactorial in design, herds with no representation in all subclasses were dropped to eliminate empty subclasses. This essentially removed herds with less than 100 records.

Years were divided into two groups; 1967-69 and later than 1969.

Age effects were examined in two classifications: $<50$ and $>50$ months.

Two seasonal classes were used, April-September and October-March.

The data were unbalanced in that unequal numbers of observations occurred in each subclass; thus, the method of unweighted means analysis was used $(24,25)$.

\section{RESULTS AND DISCUSSION}

\section{HERD EFFECTS}

The averages for milk and fat yields and fat percentages varied widely among herds (table 1). The magnitude of the standard deviations indicates a wide variation among cows within herd for these traits. Herd effects were significant $(\mathrm{P}<.05)$ for milk yield, fat yield, and fat percent (table 2). The differences among herds may be partially explained on the basis of forage quality and quantity. In general, dairymen in Puerto Rico depend more on pastures as a source of feed than dairymen in cooler 
climates; however, differences in soils, temperature conditions, and precipitation existing in Puerto Rico are such that pastures may be adequate 3 to 4 months in some areas and in others up to 9 or 10 months (29). Rate of application of fertilizer and number of animals carried per unit of land also influenced the supplies of forages. Some dairymen depended largely on green chopped grasses or sugarcane as a source of TABLE 1.-Unadjusted means and standard deviations for milk yield, fat yield (in pounds), and fat percent for 25 herds

\begin{tabular}{|c|c|c|c|c|c|c|}
\hline \multirow{2}{*}{ Herd code } & \multicolumn{2}{|c|}{ Milk yield } & \multicolumn{2}{|c|}{ Fat yield } & \multicolumn{2}{|c|}{ Fat percent } \\
\hline & Mean & S.D. & Mean & S.D. & Mean & S.D. \\
\hline & $L b$ & & $L b$ & & $\%$ & \\
\hline 1 & 9517 & 2512 & 295 & 95 & 3.08 & 0.46 \\
\hline 2 & 12067 & 3887 & 427 & 150 & 3.52 & .41 \\
\hline 3 & 10639 & 3758 & 356 & 132 & 3.34 & .25 \\
\hline 4 & 10505 & 2824 & 343 & 99 & 3.25 & .22 \\
\hline 5 & 12385 & 2970 & 398 & 108 & 3.21 & .33 \\
\hline 6 & 9251 & 2897 & 277 & 90 & 3.02 & .39 \\
\hline 7 & 7555 & 3388 & 244 & 110 & 3.26 & .36 \\
\hline 8 & 6277 & 3815 & 264 & 123 & 3.27 & .28 \\
\hline 9 & 9579 & 3702 & 321 & 134 & 3.34 & .38 \\
\hline 10 & 6662 & 3317 & 198 & 101 & 2.97 & .33 \\
\hline 11 & 8065 & 3577 & 266 & 121 & 3.32 & .27 \\
\hline 12 & 5313 & 2763 & 176 & 92 & 3.32 & .25 \\
\hline 13 & 5311 & 2391 & 169 & 77 & 3.18 & .34 \\
\hline 14 & 7715 & 3186 & 244 & 101 & 3.17 & .20 \\
\hline 15 & 5878 & 2609 & 187 & 86 & 3.17 & .36 \\
\hline 16 & 6430 & 2358 & 202 & 77 & 3.18 & .37 \\
\hline 17 & 7568 & 2697 & 238 & 88 & 3.15 & .21 \\
\hline 18 & 7823 & 3034 & 246 & 95 & 3.16 & .21 \\
\hline 19 & 7517 & 2739 & 240 & 101 & 3.32 & .44 \\
\hline 20 & 8061 & 2266 & 257 & 79 & 3.18 & .39 \\
\hline 21 & 5733 & 3412 & 189 & 114 & 3.27 & .30 \\
\hline 22 & 10014 & 3120 & 301 & 101 & 3.01 & .35 \\
\hline 23 & 8001 & 3491 & 242 & 106 & 3.08 & .40 \\
\hline 24 & 10364 & 2840 & 304 & 90 & 2.92 & .37 \\
\hline 25 & 8166 & 2919 & 246 & 95 & 3.01 & .41 \\
\hline Overall & 8457 & 3483 & 266 & 119 & 3.16 & .37 \\
\hline
\end{tabular}

forage instead of pastures, which no doubt contributed to herd differences. The usual rate of concentrate feeding was one pound per two pounds of milk, on a herd basis. Generally, all cows in milk received the same amount of concentrates each day; therefore, cows in early stages of lactation were sometimes grossly underfed. This was especially true during the poor seasons for pastures.

Herd size varied from about 40 to more than 300 cows. Based on experiences elsewhere $(4,22)$, which showed a significant negative corre- 
lation between herd size and milk production, size of herd could have contributed to differences in herd performance.

The intensity of culling of cows also tended to vary among herds. A number of herds were in a stage of rapid expansion during the period of study. It was also evident that imported cows were frequently kept long after their peak years of production. In addition, several herds had problems with brucellosis that may have influenced length of lactation. Herd averages for fat yield tended to parallel milk yields, but herd averages for fat percent did not show a distinct relation to level of milk

TABLE 2.-F-values from analysis of variance, tests of significance, and $R^{2 \%}$ for the effects of herd, year, season, age, and the interactions

\begin{tabular}{|c|c|c|c|c|}
\hline Source & d.f. & Milk yield & Fat yield & Fat percent \\
\hline & & $L b$ & $L b$ & $\%$ \\
\hline Herd $(\mathrm{H})$ & 24 & $67.86^{*}$ & $66.83^{*}$ & $26.43^{*}$ \\
\hline Year $(Y)$ & 1 & 3.55 & $26.45^{*}$ & $162.91^{*}$ \\
\hline Season $(\mathrm{S})^{1}$ & 1 & $7.76^{*}$ & $5.83^{*}$ & .28 \\
\hline Age $(A)$ & 1 & $125.24^{*}$ & $101.10^{*}$ & $9.16^{*}$ \\
\hline $\mathrm{H} \times \mathrm{S}$ & 24 & $3.81^{*}$ & $3.78^{*}$ & 1.14 \\
\hline $\mathrm{H} \times \mathrm{Y}$ & 24 & $14.99^{*}$ & $13.64^{*}$ & $12.74^{*}$ \\
\hline $\mathrm{H} \times \mathrm{A}$ & 24 & $3.61^{*}$ & $4.28^{*}$ & 1.49 \\
\hline $\mathrm{Y} \times \mathrm{S}$ & 1 & .05 & .06 & $6.14^{*}$ \\
\hline $\mathrm{A} \times \mathrm{S}$ & 1 & .40 & .03 & 1.92 \\
\hline $\mathrm{Y} \times \mathrm{A}$ & 1 & $7.66^{*}$ & $7.23^{*}$ & 1.88 \\
\hline $\mathrm{H} \times \mathrm{Y} \times \mathrm{S}$ & 24 & $3.31^{*}$ & $3.30^{*}$ & $1.92^{*}$ \\
\hline $\mathrm{H} \times \mathrm{A} \times \mathrm{S}$ & 24 & .95 & .84 & .82 \\
\hline $\mathrm{H} \times \mathrm{Y} \times \mathrm{A}$ & 24 & $1.62^{*}$ & $1.71^{*}$ & .97 \\
\hline $\mathrm{Y} \times \mathrm{A} \times \mathrm{S}$ & 1 & .47 & .18 & 1.07 \\
\hline $\mathrm{H} \times \mathrm{Y} \times \mathrm{A} \times \mathrm{S}$ & 24 & $6.29 *$ & $5.96^{*}$ & $4.81^{*}$ \\
\hline Error mean square & 10941 & $3,657,210$ & 4,154 & .006 \\
\hline $\mathrm{R}^{2} \%^{2}$ & & 39.2 & 40.1 & 23.5 \\
\hline
\end{tabular}

${ }^{1}$ Seasons: April to September and October to March.

${ }^{2}$ Squared multiple correlation coefficient.

${ }^{*} \mathrm{P}<.05$.

yield (table 1). In most herds the average fat percent was 0.3 to $0.5 \%$ below that for herds of Holsteins in temperate climates. Several factors no doubt contributed. The stress of high temperature $\left(>85^{\circ} \mathrm{F}\right)$ often caused a suppression of appetite in the first month of lactation resulting in a rapid catabolism of body reserves that influenced the rate of fat secretion $(18,20)$. Low roughage content of diets available in some herds, resulting from low yields of pastures, also caused fat percent to be less than normal. 
YEAR EFFECTS

Year effects were significant $(\mathrm{P}<.05)$ for all three traits (table 2$)$ which is in agreement with findings in both temperate and tropical areas $(8,11,13,21,28,30)$. There was a consistent decline in the yearly averages from 1967 to 1970 (table 3). The tendency for yearly averages to decline was attributed to expansion in both the number of herds on DHIA and cows per herd. The low average for 1970 was due in part to serious floods in the main dairy region along the north coast. Increased rate of culling and greater dependence on concentrates to replace the destroyed pastures probably contributed to the rise in yields for 1971 and 1972 .

It is possible, but unlikely, that the rate of importation of cattle could have affected yearly averages. Imports from 1967 to 1972 averaged about $1300 /$ year (7), but the majority of the imports went to herds either not on

TABLE 3.-Unadjusted means and standard deviations for milk and fat yield (in pounds) and percent fat by year of calving

\begin{tabular}{|c|c|c|c|c|c|c|}
\hline \multirow{2}{*}{ Year } & \multicolumn{2}{|c|}{ Milk yield } & \multicolumn{2}{|c|}{ Fat yield } & \multicolumn{2}{|c|}{ Fat percent } \\
\hline & Mean & S.D. & Mean & S.D. & Mean & S.D. \\
\hline & $L b$ & & $L b$ & & $\%$ & \\
\hline 1967 & 12692 & 2730 & 444 & 97 & 3.51 & 0.10 \\
\hline 1968 & 10762 & 3716 & 367 & 128 & 3.40 & .13 \\
\hline 1969 & 9739 & 3639 & 321 & 128 & 3.29 & .29 \\
\hline 1970 & 7964 & 3700 & 255 & 121 & 3.22 & .37 \\
\hline 1971 & 8217 & 3647 & 255 & 123 & 3.11 & .41 \\
\hline 1972 & 8481 & 3082 & 264 & 99 & 3.13 & .35 \\
\hline
\end{tabular}

DHIA at that time or those whose records were dropped during the screening process.

\section{SEASONAL EFFECTS}

Seasonal effects were significant $(P<.05)$ for milk yield and fat yield but not for percent fat (table 2). The means and standard deviations by month of calving are in table 4 . Although the four distinct changes in climatic conditions experienced in temperate regions do not occur in the tropics, two seasonal periods usually result from rainfall distribution, temperature changes, or a combination of the two. In the region where most of the herds were located, rainfall averages lower from mid-November to April than in other months. Even though the mean monthly temperature for the area was less than $6^{\circ} \mathrm{F}$ lower from December to February than for July, less rainfall, coupled with lower temperature, usually decreases the rate of growth of grasses up to $50 \%$ (29). Under 
reasonable grazing pressure the cooler season seemed to interfere with lactation yields less than in the period of high rainfall (April to August), as shown by the means of month of calving in table 4 . A low dry matter content of the pasture forages, plus a lesser diurnal variation in daily temperature conditions which placed the cows under longer periods of temperature stress, appeared to be major inhibitors for cows calving from May through August $(18,29)$.

The seasonal effects on milk and fat yields correspond to those observed in U.S. data (8), and the magnitude of the effects is large enough to warrant consideration for adjustment. Fat percent was less severely influenced by season than was milk or fat. Since the fat percent in all months is $0.3 \%$ or more below the characteristic value for the breed,

TABLE 4.-Unadjusted means and standard deviations for milk and fat yields (in pounds) and percent fat by months of calving

\begin{tabular}{|c|c|c|c|c|c|c|}
\hline \multirow{2}{*}{ Months } & \multicolumn{2}{|c|}{ Milk yield } & \multicolumn{2}{|c|}{ Fat yield } & \multicolumn{2}{|c|}{ Fat percent } \\
\hline & Mean & S.D. & Mean & S.D. & Mean & S.D. \\
\hline & $L b$ & & $L b$ & & $\%$ & \\
\hline Jan. & 8723 & 3694 & 277 & 125 & 3.18 & 0.35 \\
\hline Feb. & 8320 & 3731 & 266 & 128 & 3.19 & .35 \\
\hline Mar. & 8606 & 3716 & 277 & 128 & 3.20 & .39 \\
\hline Apr. & 8523 & 3617 & 271 & 123 & 3.18 & .39 \\
\hline May & 8265 & 3606 & 260 & 119 & 3.14 & .38 \\
\hline June & 8380 & 3520 & 264 & 117 & 3.15 & .36 \\
\hline July & 8281 & 3289 & 266 & 110 & 3.20 & .37 \\
\hline Aug. & 8369 & 3610 & 271 & 123 & 3.23 & .35 \\
\hline Sept. & 8650 & 3912 & 279 & 136 & 3.22 & .38 \\
\hline Oct. & 8958 & 3639 & 288 & 125 & 3.20 & .37 \\
\hline Nov. & 8875 & 3599 & 284 & 123 & 3.20 & .36 \\
\hline Dec. & 8800 & 3575 & 277 & 121 & 3.16 & .34 \\
\hline
\end{tabular}

it is evident that factors other than season of calving markedly influenced level of fat percentage.

AGE EFFECTS

Milk and fat yields increased with age up to approximately 6 years, then declined (table 5). Age effects were significant $(\mathrm{P}<.05)$ for both traits (table 2). A significant association of age of calving with milk and fat yields has been found in both tropical and temperate areas $(8,13,14,21,28,30,31)$. For example, Wunder and McGilliard (31) showed that 3 -year-old cows produced more than 2-year-olds in about the same ratio as for Puerto Rico. Lush and Shrode (14) found that milk yield increased until the tenth year of age, then declined; but in Puerto Rico the decline came earlier, after the sixth year (table 5). However, a decline 
after the sixth year for Holsteins has been reported from temperate regions (2).

Fat yield did not decline until the ninth year, but fat percent was lowered after first calving. Corresponding observations have been made in the temperate region (2). Since the results from temperate areas are similar to those from Puerto Rico, it appears that changes in fat yield and fat percent are largely physiological traits which exhibit themselves irrespective of climatic conditions. A negative relationship between milk and fat percent similar to that reported from temperate areas $(2,17)$ is seen in the Puerto Rico data.

TABLE 5.-Unadjusted means and standard deviations for milk and fat yields (in pounds) and percent fat by age at calving (years)

\begin{tabular}{|c|c|c|c|c|c|c|}
\hline \multirow{2}{*}{ Age } & \multicolumn{2}{|c|}{ Milk yield } & \multicolumn{2}{|c|}{ Fat yield } & \multicolumn{2}{|c|}{ Fat percent } \\
\hline & Mean & S.D. & Mean & S.D. & Mean & S.D. \\
\hline Years & $L b$ & & $\mathrm{Lb}$ & & $\%$ & \\
\hline$<2$ & 5383 & 3164 & 178 & 108 & 3.32 & 0.30 \\
\hline 2 & 7933 & 3128 & 255 & 106 & 3.23 & .38 \\
\hline 3 & 8111 & 3340 & 260 & 112 & 3.20 & .35 \\
\hline 4 & 8835 & 3595 & 282 & 121 & 3.17 & .34 \\
\hline 5 & 9159 & 3817 & 293 & 132 & 3.18 & .38 \\
\hline 6 & 9137 & 3870 & 288 & 132 & 3.16 & .40 \\
\hline 7 & 8864 & 3927 & 284 & 136 & 3.18 & .37 \\
\hline 8 & 8943 & 3905 & 288 & 136 & 3.20 & .35 \\
\hline 9 & 8620 & 3982 & 277 & 136 & 3.18 & .32 \\
\hline 10 & 8494 & 4079 & 273 & 136 & 3.21 & .32 \\
\hline 11 & 8523 & 3995 & 271 & 128 & 3.19 & .31 \\
\hline 12 & 8283 & 4400 & 264 & 147 & 3.10 & .40 \\
\hline
\end{tabular}

INTERACTION EFFECTS

Tests for the two-, three-, and four-way interaction effects showed that when herd was involved, the interactions were significant $(\mathrm{P}<.05)$, (table 2), especially for yield traits. The significant herd-year and herd-age interactions may have been due to variations among herds in culling rate or rate of additions to the herds. High supplementary feeding in some herds and not in others during some years-seasons would explain in part significance for the interactions.

Herd, year, age, season, and their interactions accounted for $39 \%$ of the variation in milk yield, $40 \%$ in fat yield, and $24 \%$ in fat percent as indicated by the squares of the multiple correlation coefficients $R^{2}$ (table 2). Components of variance, including herd, year-season, and month in one study in the United States (1), showed that without age effects in the model, $37 \%$ of the variation in milk and fat yields and about $25 \%$ of the 
variation in fat percent could be accounted for. In another study with a model that included herd, year, season, and age, $32 \%$ of the total variation in milk yield and fat yield and about $22 \%$ of that in fat percent was explained $(8,26,27)$. Error variances of 36 to $52 \%$ have been reported with similar models $(13,26)$. Total variance for milk and fat yields has tended to vary according to the population studied. VanVleck et al. (27) reported a total variance of $6,820,000 \mathrm{lb}^{2}$ for milk yield and $9,136 \mathrm{lb}^{2}$ for fat yield using only 305-day-lactation records. In the present study, the total variance was $12,980,000 \mathrm{lb}^{2}$ for milk and $15,000 \mathrm{lb}^{2}$ for fat. The higher values for variance no doubt were due in part to using a wider range in length of lactation (60 to 305 days) than used by VanVleck et al. Nevertheless, it is apparent that the amount of variation required for selection to be effective is present in the Holstein population of Puerto Rico. This is similar to the findings for temperate regions.

\section{LACTATION LENGTH, DAYS DRY AND DAYS OPEN}

Means and standard deviations for lactation length, days dry, and days open for the 25 herds are in table 6. Differences, among herds were significant for all traits $(\mathrm{P}<.05)$, (table 7 ). Correlations of 0.50 to 0.60 between lactation length and yields of milk and fat occurred in both Puerto Rico (6) and elsewhere (17). Level of feeding is an important factor in length of lactation. Low levels of feeding prior to parturition bring about an earlier peak in daily yields and generally shorten the length of lactation $(5,18)$. About $30 \%$ of the variation in the length of first lactation for Holsteins can be accounted for by variation in feeding (16).

Herd size does not appear to influence lactation length (4). Environmental factors have more influence on lactation length than genetic factors as indicated by heritability estimates (17).

Differences among herds in length of dry period may be caused by differences in level of feeding (17). That environmental conditions are the major causes for variation in length of dry period is supported by heritability estimates of near zero for this trait $(17,23)$.

Differences among herds in days open could have been due to the relative importance given by herd managers to reproductive performance, i.e., due more to failure to detect estrus and breeding at the optimum time than to disease problems or heat stress.

The yearly averages for all herds (table 8 ) showed significant changes $(\mathrm{P}<.05)$, (table 7). Average lactation length tended to decline from 1967 to 1972 while days dry rose. The standard deviations increased from 1967 to 1972. No explanation can be offered for these trends; however, it was observed that length of time cows milked in first lactation declined after 1968 and so did the dry period following second lactation. This suggests that heifers were not grown out as well as in the earlier years. 
Season of calving had a significant influence only on days open (table 7), whereas in temperate areas length of lactation was influenced by season of calving (5), and the month of calving significantly influenced length of dry period (23). Cows calving from May to October (table 9) were above average in days open, which agrees with findings from Florida (9) and Louisiana (5).

Age effects were significant only for days dry (table 7). There was a

TABLE 6.-Herd means and standard deviations for lactation length (days), days dry, and days open

\begin{tabular}{|c|c|c|c|c|c|c|}
\hline \multirow{2}{*}{$\begin{array}{l}\text { Herd } \\
\text { code }\end{array}$} & \multicolumn{2}{|c|}{ Lactation length } & \multicolumn{2}{|c|}{ Days dry } & \multicolumn{2}{|c|}{ Days open } \\
\hline & Mean & S.D. & Mean & S.D. & Mean & S.D. \\
\hline 1 & 280 & 39.9 & 103 & 54.5 & 137 & 68.1 \\
\hline 2 & 285 & 47.3 & 104 & 74.2 & 169 & 79.2 \\
\hline 3 & 275 & 52.8 & 149 & 110.0 & 153 & 71.0 \\
\hline 4 & 287 & 43.0 & 85 & 65.8 & 156 & 73.8 \\
\hline 5 & 293 & 34.6 & 86 & 64.8 & 155 & 73.4 \\
\hline 6 & 282 & 48.2 & 105 & 74.8 & 146 & 69.6 \\
\hline 7 & 246 & 79.8 & 101 & 64.3 & 137 & 76.9 \\
\hline 8 & 252. & 72.2 & 134 & 94.1 & 136 & 73.1 \\
\hline 9 & 260 & 70.4 & 125 & 111.5 & $14 \%$ & 69.4 \\
\hline 10 & 252 & 80.1 & 79 & 72.6 & 160 & 73.2 \\
\hline 11 & 250 & 74.1 & 111 & $96 \%$ & 128 & 70.5 \\
\hline 12 & 227 & 80.2 & 109 & 80.1 & 127 & 61.8 \\
\hline 13 & 237 & 73.3 & 1,31 & 96.1 & 104 & 50.5 \\
\hline 14 & 257 & 68.3 & 115 & 60.8 & 163 & 75.6 \\
\hline 15 & 243 & 72.2 & 124 & 113.1 & 125 & 66.7 \\
\hline 16 & 283 & 48.5 & 123 & 87.3 & 155 & 80.0 \\
\hline 17 & 266 & 34.7 & 106 & 68.0 & 143 & 69.8 \\
\hline 18 & 243 & 65.6 & 121 & 126.4 & 118 & 60.6 \\
\hline 19 & 276 & 66.3 & 80 & 48.0 & 168 & .000 \\
\hline 20 & 279 & 42.4 & 133 & 103.0 & 107 & 56.5 \\
\hline 21 & 214 & 96.2 & 94 & 76.1 & 146 & 81.3 \\
\hline 22 & 285 & 50.0 & 102 & 82.1 & 141 & 69.6 \\
\hline 23 & 249 & 82.3 & 129 & 64.7 & 118 & 67.1 \\
\hline 24 & 284 & 45.4 & 111 & 83.4 & 129 & 64.2 \\
\hline 25 & 266 & 65.7 & 109 & 74.1 & 132 & 68.3 \\
\hline All & 265 & 64.1 & 102 & 78.0 & 137 & 71.2 \\
\hline
\end{tabular}

linear increase of days dry with age (table 10). In general, cows over 6 years of age had the longest dry periods. This is in agreement with results both from New York (23) and Venezuela (3), where age significantly influenced the length of the dry period. That lactation length and days open did not vary with age is in disagreement with some of the studies from the temperate region $(5,10)$.

Herd-season, herd-year, and herd-year-season interactions were signif- 
icant for lactation length, days dry, and days open (table 7). This suggests failure of adjustment on some farms to changes associated with seasons and years, especially to the managment of feed resources. The interaction of herd-year-age-season was also significant for the three traits.

The fitted model, with herd, year, age, and seasonal effects considered, accounted for 17,13 , and $12 \%$, respectively, of the variation in lactation length, dry period, and days open, as indicated by the squared multiple correlation coefficients $\left(\mathrm{R}^{2}\right)$, (table 7 ). The heritabilities for these traits are small (17); thus the conclusion that environmental variation deter-

TABLE 7.-F-values from analysis of variance and tests of significance for the effects of herd, year, season, age, and the interactions on lactation length, days dry, and days open

\begin{tabular}{lrccc}
\hline \multicolumn{1}{c}{ Effects } & d.f. & Lactation length & Days dry & Days open \\
\hline Herd $(\mathrm{H})$ & 24 & $22.09^{*}$ & $5.19^{*}$ & $9.73^{*}$ \\
Year $(\mathrm{Y})$ & 1 & $5.85^{*}$ & $14.98^{*}$ & $8.61^{*}$ \\
Season $(\mathrm{S})^{1}$ & 1 & 1.37 & .80 & $13.94^{*}$ \\
Age $(\mathrm{A})$ & 1 & .35 & $22.76^{*}$ & .47 \\
$\mathrm{H} \times \mathrm{S}$ & 24 & $4.52^{*}$ & $1.74^{*}$ & $1.91^{*}$ \\
$\mathrm{H} \times \mathrm{Y}$ & 24 & $9.45^{*}$ & $3.79^{*}$ & $3.96^{*}$ \\
$\mathrm{H} \times \mathrm{A}$ & 24 & $1.65^{*}$ & 1.54 & 1.49 \\
$\mathrm{Y} \times \mathrm{S}$ & 1 & .07 & .08 & .26 \\
$\mathrm{~A} \times \mathrm{S}$ & 1 & .16 & 7.06 & $4.81^{*}$ \\
$\mathrm{Y} \times \mathrm{A}$ & 1 & 1.03 & 1.39 & .03 \\
$\mathrm{H} \times \mathrm{Y} \times \mathrm{S}$ & 24 & $4.31^{*}$ & $2.30^{*}$ & $2.63^{*}$ \\
$\mathrm{H} \times \mathrm{A} \times \mathrm{S}$ & 24 & 1.29 & .74 & .71 \\
$\mathrm{H} \times \mathrm{Y} \times \mathrm{A}$ & 24 & 1.32 & 1.02 & 1.34 \\
$\mathrm{Y} \times \mathrm{A} \times \mathrm{S}$ & 1 & .00 & .00 & .04 \\
$\mathrm{H} \times \mathrm{Y} \times \mathrm{A} \times \mathrm{S}$ & 24 & $6.47^{*}$ & $4.27^{*}$ & $4.65^{*}$ \\
Error mean squares & 10941 & 176 & 629 & 5851 \\
$\mathrm{R}^{2}{ }^{2}$ & & 16.8 & 12.7 & 11.7 \\
\hline
\end{tabular}

'Seasons: April to September and October to March.

${ }^{2}$ Squared multiple correlation coefficient.

$* \mathrm{P}<.05$.

TABLE 8.-Means and standard deviations for lactation length (days), days dry, and days open by year of freshening

\begin{tabular}{|c|c|c|c|c|c|c|}
\hline \multirow{2}{*}{ Year } & \multicolumn{2}{|c|}{ Lactation length } & \multicolumn{2}{|c|}{ Days dry } & \multicolumn{2}{|c|}{ Days open } \\
\hline & Mean & S.D. & Mean & S.D. & Mean & S.D. \\
\hline 1967 & 296 & 15.8 & 96 & 76.7 & 171 & 89.5 \\
\hline 1968 & 277 & 52.0 & 100 & 80.4 & 152 & 80.0 \\
\hline 1969 & 273 & 55.1 & 89 & 81.2 & 165 & 82.2 \\
\hline 1970 & 255 & 75.6 & 104 & 77.8 & 142 & 80.1 \\
\hline 1971 & 262 & 67.4 & 118 & 95.5 & 148 & 80.9 \\
\hline 1972 & 275 & 52.3 & 109 & 82.0 & 153 & 79.4 \\
\hline
\end{tabular}


TABLE 9.-Means and standard deviations for lactation length (days), days dry, and days open by months of freshening

\begin{tabular}{|c|c|c|c|c|c|c|}
\hline \multirow{2}{*}{ Months } & \multicolumn{2}{|c|}{ Lactation length } & \multicolumn{2}{|c|}{ Days dry } & \multicolumn{2}{|c|}{ Days open } \\
\hline & Mean & S.D. & Mean & S.D. & Mean & S.D. \\
\hline Jan. & 264 & 64.5 & 115 & 91.1 & 144 & 84.5 \\
\hline Feb. & 257 & 69.8 & 114 & 89.1 & 148 & 85.4 \\
\hline Mar. & 261 & 67.1 & 110 & 86.9 & 145 & 84.0 \\
\hline Apr. & 262 & 67.6 & 115 & 83.3 & 146 & 87.2 \\
\hline May & 259 & 73.1 & 111 & 77.6 & 151 & 85.4 \\
\hline June & 264 & 65.1 & 119 & 91.0 & 158 & 84.6 \\
\hline July & 265 & 63.5 & 109 & 82.4 & 159 & 77.5 \\
\hline Aug. & 265 & 67.3 & 112 & 86.8 & 162 & 75.1 \\
\hline Sept. & 265 & 66.8 & 107 & 86.1 & 159 & 75.9 \\
\hline Oct. & 273 & 58.3 & 95 & 79.4 & 156 & 77.5 \\
\hline Nov. & 272 & 56.8 & 97 & 79.0 & 148 & 80.1 \\
\hline Dec. & 268 & 59.6 & 109 & 86.5 & 142 & 79.3 \\
\hline
\end{tabular}

TABLE 10.-Means and standard deviations for lactation length (days), days dry, and days open by age at calving (years)

\begin{tabular}{|c|c|c|c|c|c|c|}
\hline \multirow{2}{*}{ Age } & \multicolumn{2}{|c|}{ Lactation length } & \multicolumn{2}{|c|}{ Days dry } & \multicolumn{2}{|c|}{ Days open } \\
\hline & Mean & S.D. & Mean & S.D. & Mean & S.D. \\
\hline \multicolumn{7}{|l|}{ Years } \\
\hline$<2$ & 209 & 92.2 & - & - & 119 & 87.2 \\
\hline 2 & 270 & 62.5 & 75 & 56.1 & 160 & 78.9 \\
\hline 3 & 265 & 65.3 & 93 & 69.5 & 151 & 80.4 \\
\hline 4 & 265 & 62.4 & 101 & 77.9 & 151 & 80.3 \\
\hline 5 & 266 & 63.3 & 110 & 84.8 & 151 & 79.9 \\
\hline 6 & 265 & 65.5 & 114 & 91.2 & 150 & 81.8 \\
\hline 7 & 264 & 65.3 & 119 & 97.8 & 152 & 83.2 \\
\hline 8 & 270 & 60.0 & 120 & 99.7 & 152 & 81.7 \\
\hline 9 & 260 & 68.8 & 121 & 90.5 & 154 & 83.6 \\
\hline 10 & 255 & 73.8 & 117 & 91.6 & 140 & 81.1 \\
\hline 11 & 264 & 64.8 & 131 & 78.5 & 151 & 77.8 \\
\hline 12 & 251 & 86.2 & 112 & 70.8 & 140 & 91.9 \\
\hline
\end{tabular}

mines the expression of these traits more than genotype is justified. No doubt factors other than those examined influenced these traits.

Although it will be desirable eventually to make a study involving more herds over a longer time period, the results from the current study show that the influence of environment on the performance of Holsteins in Puerto Rico is relatively similar to that in cooler climates. The estimates of components of variance indicate that the influence of genotype is as strong in the tropics as in temperate regions, and the influence of the environment is neither more nor less. 


\section{RESUMEN}

Se determinó el efecto del hato, el año, la edad, la estación y sus interacciones en la produccion de leche y grasa láctea, el contenido de grasa láctea, los días en producción de leche, los días en el período seco y los días en el período receptivo para vacas Holstein puras o de alto grado de pureza en un ambiente tropical mediante el uso de análisis de varianza. Se utilizaron alrededor de 1900 de los 33,950 registros de producción de leche completados en Puerto Rico por vacas Holstein en 62 hatos inscritos en la asociación para el mejoramiento de hatos lecheros del 1967 al 73 . Los efectos del hato fueron significativos $(\mathrm{P}<.05)$ para todas las variables pero los efectos de la estación fueron significativos solo para la producción de leche, grasa y días en el período receptivo. La variación entre vacas influyó significativamente $(\mathrm{P}<.05)$ en todas las variables excepto en la producción de leche. La edad de la vaca al parir afectó todas las variables excepto la duración de la lactación y el período receptivo. Un número de las interacciones fue también significativo.

El modelo estadístico explicó el $39,40,24,17,13$ y 12\% de la variación total en la producción de leche, grasa, contenido de grasa, duración de la lactación, días en el periodo seco y en el receptivo, respectivamente. Las varianzas totales fueron $12,900,000 \mathrm{lb}^{2}$ para la producción de leche y $15,000 \mathrm{lb}^{2}$ para la producción de grasa, comparables a las de zonas templadas

Se concluyó que los factores que afectan el comportamiento de vacas Holstein en Puerto Rico no difieren marcadamente de aquéllos en zonas templadas. La variación total es lo suficientemente amplia para permitir la selección de animales para una producción mayor de leche $y$ de grasa. Al igual que en las zonas templadas, la duración de lactación y del periodo seco y el tiempo de días receptivos dependen mayormente de las decisiones de los ganaderos.

\section{LITERATURE CITED}

1. Bereskin, B., and Freeman, A. E., Genetic and environmental factors in dairy sire evaluation. I. Effects of herds, months and year-seasons of variance among lactation records; repeatability and heritability, J. Dairy Sci., 48: 347-51, 1965.

2. Blanchard, R. P., Freeman, A. E., and Spike, P. W., Variation in lactation yield, J. Dairy Sci., 49: 953-6, 1966.

3. Badisco, V., Cevallos, E., Rincón, E. J., Mazzarri, G., and Fuenmayor, C., Effect of some environmental and physiological factors on milk production in Holstein-Friesian and Brown Swiss cows at Maracay, Venezuela, Agron. Trop., 21: 549-63, 1971.

4. Brown, C. A., and White, J. M., Management factors associated with herd average milk yiuld and income over feed costs in Guernsey, Holstein and Jersey herds, J. Dairy Sci, 56: $789-98,1973$.

5. Branton, C., Ríos, G., Evans, D. L., Farthing, B. R., and Koonce, K. L. Genotypeclimatic and other interaction effects for productive responses in Holsteins, J. Dairy Sci., 57: 833-41, 1974.

6. Camoens, J. K., McDowell, R. E., VanVleck, L. D., and Rivera Anaya, J. D., Holsteins in Puerto Rico. II. Influence of lactation length, days dry, days open and calving interval on production traits, J. Agr. Univ. P. R., 60 (4): 540-50, 1976.

7. Department of Agricultural Economics, and Rural Sociology, Costs and returns in production of milk on first class dairy farms in Puerto Rico, 1959 and estimates for 1974, Agr. Exp. Sta. Univ. P.R., July 1974.

8. Gacula, M. C., Jr., Gaunt, S. N., and Damon, R. A., Jr., Genetic and environmental parameters of milk constituents for five breeds. I. Effects of herd, year, season, and age of cow. J. Dairy Sci., 51: 428-37, 1968.

9. Gwazdauskas, F. C., Wilcox, W. J., and Thatcher, W. W. Environmental and 
management factors affecting conception in a subtropical climate, J. Dairy Sci., 58: 88-92, 1975.

10. Hamilton, R. R., and Hillers, J. K., Factors affecting persistency of daily milk production, J. Dairy Sci., 56: 674, 1973.

11. Hardie, A. R., Jensen, E. L., and Tyler, W. J., Genetic, phenotypic, and economic relationships among yields of milk and its components, J. Dairy Sci., 55: 690, 1972.

12. Hayman, R. H., The development of the Australian Milking Zebu, World Anim. Rev. 11: $31-5,1974$.

13. Lee, A. J., Month, year, herd effects on age adjustment of first lactation milk yield, J. Dairy Sci., 57: 332-8, 1974.

14. Lush, J. L., and Shrode, R. R., Changes in milk production with age and milking frequency, J. Dairy Sci., 33: 338-57, 1950.

15. Mason, I. L., Maintaining crossbred populations of dairy cattle in the tropics, World Anim. Rev., 11:36-43, 1974.

16. McDowell, R. E., Effect of environment on the functional efficiency of ruminants, Proc. Int. Livestock Symp., Spec. Pub. SP-0174, Amer. Soc. Agr. Eng., pp 220-31, 1974.

17. - Improvement of livestock production in warm climates, W. H. Freeman \& Co., San Francisco, 1972.

18. - Cestero, H., Rivera Anaya, J. D., Román, F., Arroyo-Aguilú, J. A., Berrocal, C. M., Soldevila, M., López-Alberty, J. C., and Metz, S. W., Tropical grass pastures with and without supplement for lactating cows. Univ. P. R., Agr. Exp. Sta. Bull. 238, 1975.

19. McLaren, L. E., The development of the Jamaica Hope breed of dairy cattle, Min. Agr. Anim. Husb. Bull. No. 2 (77 pp.), Kingston, 1972.

20. Moody, E. G., VanSoest, P. J., McDowell, R. E., and Ford, G. L., Effect of high temperature and dietary fat on milk fatty acids, J. Dairy Sci., 54: 1457-60, 1971.

21. Ngere, L. O., McDowell, R. E., Bhattacharya, S., and Guha, H., Factors influencing milk yield of Hariana cattle, J. Anim. Sci., 36: 457-65, 1973.

22. Rathore, A. K., The influence of herd size on milk production, XVIII Int. Dairy Congr., Sydney, Australia, Vol. 1E: 580, 1970.

23. Schaeffer, L. R., and Henderson, C. R., Effects of days dry and days open on Holstein milk production, J. Dairy Sci., 55: 107-12, 1972.

24. Searle, S. R., Linear models, Wiley \& Sons, N. Y., 1971.

25. Snedecor, G. W., and Cochran, W. G., Statistical models, 6th ed, Iowa State Univ. Press, Ames, 1967.

26. Spalding, R. W., Henderson, C. R., Carter, H. W., Albrectsen, R., and Meek, A. M., The selection and evaluation of dairy sires. N. Y. State Coll. Agr. Ext. Bull. 1118, Ithaca, 1963.

27. Van Vleck, L. D., Wadell, L. H., and Henderson, C. R., Components of variance associated with milk and fat records of artifically sired Holstein daughters, J. Anim. Sci., 20: 812-16, 1961.

28. Verde, O. G., Wilcox, W. J., Koger, M., Plasse, D., and Martin, F. G., Estimation of several genetic parameters for milk yield in three Venezuela herds, J. Dairy Sci., 53: $674,1970$.

29. Vicente-Chandler, J., Abruña, F., Caro-Costas, R., Figarella, J., Silva, S., and Pearson, R. W., Intensive grassland management in the humid tropics of Puerto Rico, Univ. P. R., Agr. Exp. Sta. Bull. 233, 1974.

30. Wellington, K. E., Mahadevan, P., and Roache, K. L., Production characteristics of the Jamaica Hope breed of dairy cattle, J. Agr. Sci., Camb., 74: 463-8, 1970.

31. Wunder, W. W., and McGilliard, L. D., Seasons of calving, age, management and genetic differences for milk. J. Dairy Sci., 54: 1652-61, 1971. 